\title{
Effect Of Kartodim 315ec (Dimethoate) and Lambda - (Cyhalothrin) On Electrolytes of Clarias Gariepinus.
}

\author{
E.N. Ogamba, I.R. Inyang and O.C Okechukwu \\ Department of Biological Sciences, Niger Delta University, Wilberforce Island, PMB 071 Yenagoa, Bayelsa \\ State, Nigeria.
}

\begin{abstract}
Changes in the Sodium $\left(\mathrm{Na}^{+}\right)$, Potassium $\left(\mathrm{K}^{+}\right)$and Calcium $\left(\mathrm{Ca}^{+}\right)$ions of the fish, Clarias gariepinus, (Burchell; 1822) subjected to sub lethal concentrations $(0.01$ and $0.02 \mathrm{ml}$ ) of Kartodim 315 EC (Dimethoate and Lambda-Cyhalothrin), a pesticide, over a period of 96 hours were studied in a semi- static (renewal) system. The result indicated that the $\mathrm{Na}^{+}, \mathrm{K}^{+}$and $\mathrm{Ca}^{2+}$ in the liver exhibited a sight fluctuation in their values, with $\mathrm{Na}^{+}$and $\mathrm{K}^{+}$increasing while $\mathrm{Ca}^{2+}$ decreased $(P>0.05)$ with increased concentrations of Kartodim $315 \mathrm{EC}$. For the kidney electrolytes, their was a significant $(P<0.05)$ decrease in value with increased concentrations of Kartodim $315 \mathrm{EC}$, with the exception of sodium $\left(\mathrm{Na}^{+}\right)(\mathrm{P}>0.05)$. The overall pictures of changes in the composition of ion concentration does not exclude the possibility of kidney damage in the experimental fish. The ions (electrolytes) provide some information on the osmotic pressure and osmoregulatory changes in the fish. The kidney and Liver electrolytes are all involved in general ion regulation and in cell membrane processes. Keywords: Dimethoate and Lambda- cyhalothrin, Clarias gariepinus, Electrolytes, Kidney, Liver.
\end{abstract}

\section{Introduction}

Pesticide, according to food and Agricultural organization is any substance or mixture of substances intended for preventing, destroying or controlling any pest including vectors of human or animal disease, unwanted species of plants or animals causing harm during or interfering with the production, processing, storage, transport or marketing of food, agricultural commodities, woods and wood products and animal feedstuffs, or substances which may be administered to animals for the control of insects, arachnids or other pests in or on their bodies. The term includes substances intended for use as a plant growth regulator, defoliant, desiccant or agent for thinning fruit or preventing the premature fall of fruit. Also, used as substances applied to crops either before or after harvest to protect the commodity from deterioration during storage and transport.

Organophosphate and pyrethroid insecticides are pesticides widely used today since the removal of organochlorine insecticides from use. Organophosphate insecticides are used in agriculture, in homes, in gardens, and in veterinary practice. All apparently share a common mechanism of cholinesterase inhibition and can cause similar symptoms. Thus, it is important to understand that there is a wide range of toxicity and variation in cutaneous absorption of these agents, making specific identification and management quite important (Adedeji et al; 2009).

Biochemical changes induced by pesticidal stress leads to metabolic disturbances of important enzymes, retardation of growth and reduction in the fecundity and longevity of the organism. Liver, kidney, brain and gill are the most valuable organs of a fish exposed to the medium containing any type of toxicant. The fish show restlessness, rapid body movement, convulsion, difficulty in respiration, excess mucus secretion, change in colour, and loss of balance when exposed to pesticides (Tham, et al; 2009)

Fish is one of the organisms of choice for the bioassay of a variety of toxicants such as detergents

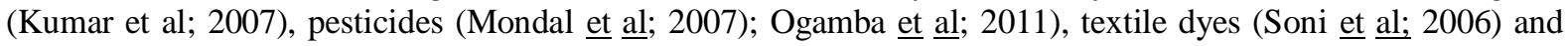
heavy metals (Oyewo and Donpedro, 2006).

Clarias gariepinus is a fresh water fish and an important food supply for humans. Several studies on Clarias gariepinus (African catfish) have been carried out by various researchers including Adeyemo (2003) and Ogamba (2011). Clarias garcepinus is widely distributed in Africa with its native range extending from South Africa through central, West and North Africa into the middle East and Eastern Europe. It is indigenous to many rivers from nile to the orange River and has been found at altitudes of 1400m in Northern Kwazulu Natal (De Moor and Bruton, 1988). Being a freshwater fish, Clarias gariepinus is often found in rivers, dams, lakes, swamps, muddy waters, flood plains and other water bodies. It can burry itself in the river bed of muddy waters or ponds when there is a decrease in water level, gulping air directly using accessory breathing organ instead of gills (De Moor and Bruton, 1988). This species of fish has been reported to be a sensitive biomarker for carbamate such as cabaryl (Parveen et al, 2004). The blood of fish is sensitive to pollution induced stress and certain serum chemistry may be used to identify tissue damage (Patil and Kulkarni, 1993). Manerals are mainly responsible for the maintenance of Osmotic pressure in blood and proper function of all types of tissues (Mohanty and Mishra, 1983). The electrolytes are essential for the activity of many enzymes (Joshi, 2000). 
Kartodim 315 EC is a trade name for the insecticide containing Lambda-Cyhalothrin $15 \mathrm{~g} / \mathrm{L}$ and Dimethoate 300g/L. Kartodim 315 EC comes in emulsifiable concentrate. Lambda-Cyhalothrin, a synthelic and Lipophilic insecticide, belongs to the pyrethroid Chemical class of pesticides. All Pyrethroid insecticides are neurotoxins. Lambda-Cyhalothrin Targets a wide range of insects including' aphids, beetles, butterfly larvae, cockroaches, mosquitoes, ticks and flies (Beat et al., 1997).

Dimenthoate is an organophosphate insecticide used against a wide range of insects. Organophosphates act by interfering with the activities of cholinesterase, an enzyme that is essential for the proper working of the nervous system of both humans and insects. They are toxic by all routes of exposure.

Several researchers have assessed the effect of various pesticides on the behaviours, biochemical and haematological responses of various species of fish (Anees, 1987; Benarji and Rajendranath, 1990; Svoboda etal, 2001) and have found varying responses after exposing the fish to varying sub-lethal concentrations using 96 hours acute toxicity tests. The purpose of this study is to assess the changes in Eleoctrolyte levels in cultured African Catfish, Clarias gariepinus, following exposure to Lambda-Cyhalothrin and dimethoate insecticides.

\section{Experimental Procedure:}

\section{Materials And Methods}

One hundred and twenty healthy adult Clrias gariepins (Mean Weight 166.70 $\pm 0.33 \mathrm{gSD}$, mean length $22.43 \pm 2.42 \mathrm{~cm} \mathrm{SD}$ ) were Obtained from Aluu, University of Port Harcourt, Port Harcourt. They were transported in 50 litre trough (whose mouth was covered by a net) by car to the Department of Biological Sciences, Niger Delta University. On arrival, the fish were acclimated individually in rectangular aquaria for seven days. The water was changed daily and the aquaria washed with a piece of foam. The fish were fed once a day with $35 \%$ crude protein at $1 \%$ biomass daily (10.00am - 11.00am).

A range finding test was carried out using the toxicant kartodim 315EC, a synthetic organophosphate insecticide. Three concentrations of kartodim 315EC obtained from Diazenhoff Nigeria limited, Port Harcourt were prepared from the original solution using the method described by Grinshaw (1978). The trial test was set up in three (3) groups of $0.00 \mathrm{ppm}, 0.01 \mathrm{ppm}$ and $0.02 \mathrm{ppm}$. Five (5) fishes were exposed to each concentration of kartodim 315EC. The test solution was received daily as in the acclimating period for seven days. The purpose of the test was to determine the range of concentration to be used for the definitive test.

Sub-lethal concentrations for the definitive test were done based on the range finding test. The fish were divided randomly into three (3) groups of fish per group. Each group further divided into three replicate groups of 10 fishes per replicate. The fishes in group 1 were exposed to tap water only as the control, while the fish in groups 2 and 3 were treated with $0.01 \mathrm{ppm}$ and $0.02 \mathrm{ppm}$ of the toxicant in tap water. The water and toxicant in each group were renewed daily. The experiment lasted for 96 hours (4 days).

\section{Sample Collection}

At the end of the experiment, fish were killed and dissected for collection of kidney and liver samples. Then $0.5 \mathrm{~g}$ of each of the organs were macerated with pestle and mortar. $5 \mathrm{mls}$ of deionized water was added to each of the samples and then the samples were centrifuged at the rate of 3000rpm for 10 minutes. The supernatant were then removed and stored in plain bottles at $20^{\circ} \mathrm{C}$ for electrolyte analysis.

\section{Physicochemical Parameters of Aquaria Water}

Physicochemical parameters such as $\mathrm{pH}$, conductivity; alkalinity, turbidity, salinity and dissolved oxygen (DO) were measured on daily basis according to the standard methods described in the guidelines of APHA (1998).

\section{Physicochemical parameters of Exposed Aquaria}

\section{Results And Discussion}

The fluctuations in the mean values of the water quality parameters were minimal throughout the period. All the values recorded were comparable to the value of the control experiment, with no clear relationships displayed between the parameters and the concentration of Kartodim 315EC (dimethoate and lambda cyhalothrin). However, dissolved oxygen (DO) was the only exception with the mean values decreasing with increase in the dimethoate and lambda - cyhalothrin concentration. The DO concentration in the control experimenty was $7.210 .02 \mathrm{SD}$, while the $\mathrm{DO}$ value at the highest concentration of the toxicant $(0.02 \mathrm{ppm})$ was $6.61+0.05 \mathrm{SD}$. 
Table 1: Physicochemical parameters of Aquaria water

Mean + SD.

\begin{tabular}{|l|l|l|l|l|l|}
\hline $\begin{array}{l}\text { Concentra-tion of } \\
\text { Kartodim }\end{array}$ & Alkalinity & pH & Conductivity & Turbidity & Dissolved Oxygen (DO) \\
\hline $\begin{array}{l}315 \mathrm{EC} \\
0.00 \mathrm{ml}\end{array}$ & $12.22 \pm 0.78$ & $6.27 \pm 0.08$ & $99.50 \pm 21.46$ & $0.25 \pm 0.45$ & $7.21 \pm 0.02$ \\
\hline $0.01 \mathrm{ml}$ & & & & & \\
\hline $0.02 \mathrm{ml}$ & $12.40 \pm 0.84$ & $6.37 \pm 0.07$ & $105.80 \pm 80.00$ & $0.20 \pm 0.40$ & $6.28 \pm 0.05$ \\
\hline
\end{tabular}

\section{Electrolytes}

The result of the liver and kidney electrolytes; sodium $\left(\mathrm{Na}^{+}\right)$, potassium $\left(\mathrm{K}^{+}\right)$and Calcium $\left(\mathrm{Ca}^{2+}\right)$, following the 96 hours exposure of the African Catfish (Clarias gariepinus) to the various concentrations of Kartodim 315EC (dimethoate and lambda - Cyhalothrin) are presented in tables 2 and 3 below.

Table2: liver Electrolyte values (mg/l) at the different concentrations of Kartodim 315EC.

\begin{tabular}{|l|l|l|l|}
\hline $\begin{array}{l}\text { Kartodim 315EC } \\
\text { concentrations }\end{array}$ & $\begin{array}{l}\text { Sodium } \\
\text { values }\end{array}$ & potassium $\left(\mathrm{K}^{+}\right)$values & Calcium $\left(\mathrm{Ca}^{2+}\right)$ values \\
\hline $0.00 \mathrm{ml}$ & $15.60 \pm 2.10$ & $12.10 \pm 0.00$ & $1.20 \pm 2.01$ \\
\hline $0.01 \mathrm{ml}$ & $18.60 \pm 0.02$ & $12.09 \pm 0.20$ & $0.60 \pm 0.85$ \\
\hline $0.02 \mathrm{ml}$ & $14.30 \pm 0.00$ & $9.00 \pm 0.90$ & $0.60 \pm 0.71$ \\
\hline
\end{tabular}

Table 3: Kidney Electrolyte values (mg/l) at the different concentrations of Kartodim 315EC

\begin{tabular}{|l|l|l|l|}
\hline $\begin{array}{l}\text { Kartodim } \\
\text { concentrations }\end{array}$ & Sodium $\left(\mathrm{Na}^{+}\right)$values & potassium $\left(\mathrm{K}^{+}\right)$values & Calcium $\left(\mathrm{Ca}^{2+}\right)$ \\
\hline $0.00 \mathrm{ml}$ & $16.40 \pm 0.02$ & $10.60 \pm 1.01$ & $2.00 \pm 0.03$ \\
\hline $0.01 \mathrm{ml}$ & $10.50 \pm 0.10$ & $7.20 \pm 1.20$ & $1.60 \pm 0.20$ \\
\hline $0.02 \mathrm{ml}$ & $13.90 \pm 0.50$ & $5.90 \pm 0.02$ & $0.60 \pm 0.65$ \\
\hline
\end{tabular}

The result of the liver electrolyte analysis of the experimental and control groups showed that the fish exposed to $0.01 \mathrm{ml}$ (group11) of Kartodim 315EC had a slight increase in sodium values (18.6+ 0.02) as against the control group (group 1) which had $15.6+2.10$ as sodium values. On the other hand, fish exposed to $0.02 \mathrm{ml}$ (group III) of Kartodim 315EC, showed a significant $(\mathrm{p}<0.05)$ decrease $(14.30+0.00)$ in the sodium values as against groups I and II $(0.00 \mathrm{ml}$ and $0.01 \mathrm{ml})$ with $15.60+2.10$ and $18.60+0.02 \mathrm{mg} / \mathrm{l}$ respectively (Table 2$)$.

The potassium $\left(\mathrm{K}^{+}\right)$values exhibited similar trend to sodium, decreasing slightly in group II (O. $01 \mathrm{ml}$ of Kartodim $315 \mathrm{EC})$ with a value of $12.09 \pm 0.20 \mathrm{Mg} / \mathrm{L}$, while group III $(0.02$, ml of Kartodim $315 \mathrm{EC})$ showed significant $(\mathrm{P}<0.05)$ decrease in the concentration of Potassium with a value of $9.00 \pm 0.90 \mathrm{mg} / \mathrm{l}$.

The Calcium values in the liver of groups II and III were significantly $(\mathrm{P}<0.05)$ lower than the control $(1.20 \pm 2.01 \mathrm{mg} / \mathrm{l})$, with values of $0.60 \pm 0.85 \mathrm{mg} / \mathrm{l}$ and $0.60 \pm 0.71 \mathrm{mg} / \mathrm{l}$ respectively. However, there was no significant $(\mathrm{P}>0.05)$ difference between group II and group III values.

In the kidney however, the electrolytes; sodium $\left(\mathrm{Na}^{+}\right)$potassium $\left(\mathrm{K}^{+}\right)$and calcium $\left(\mathrm{Ca}^{2+}\right)$ were significantly $(\mathrm{P}<0.05)$ lower in the exposed groups than the control. The sodium level in the control group was $16.40 \pm 0.02 \mathrm{mg} / \mathrm{l}$ while the test groups II and III had $10.50 \pm 0.10 \mathrm{mg} / \mathrm{l}$ and $13.90 \pm 0.50 \mathrm{mg} / \mathrm{l}$ respectively. Test group II had the lowest sodium level. On the other hand, potassium and calcium showed similar trends with the test group III values $(5.90 \pm 0.02 \mathrm{mg} / \mathrm{l}$ for potassium and $0.60 \pm 0.65 \mathrm{mg} / \mathrm{l}$ for calcium) being significantly $(\mathrm{P}<0.05)$ lower than the test group II values $(7.20 \pm 1.20 \mathrm{mg} / \mathrm{l}$ for potassium and $1.60 \pm 0.20 \mathrm{mg} / \mathrm{l}$ for calcium) respectively.

The electrolyte balance of the body is an important factor in fluid distribution, intra and extra cellular acidobasic equilibrium, maintaining osmotic pressure of the body fluids and normal neuro-muscular irritability (Harper, 1977). All the electrolytes with the exception of sodium level in the liver (at 0.01ml of Kartodim, 315EC) decreased with exposure to Kartodim 315EC. Concentration - dependent pattern was also observed for potassium $\left(\mathrm{K}^{+}\right.$and calcium $\left(\mathrm{Ca}^{2+}\right)$ as the values for both liver and kidney of fish in group II $(0.02 \mathrm{ml}$ of Kartodim) were significantly $(\mathrm{P}<0.05)$ lower than those of fish in group II $(0.01 \mathrm{ml}$ of Kartodim). The mean values of liver and kidney electrolytes of the experimental fish varied from the control group. Sodium $\left(\mathrm{Na}^{+}\right)$ levels of the experimental fish however, were not significantly $(\mathrm{P}>0.05)$ different from those of the control group. There were no significant $(\mathrm{P}>0.05)$ variations in the mean values of the water quality parameters throughout the study period. The values recorded in this study have been reported to be within the tolerance ranges of warm water fish species (Ogamba et al; 2011). Therefore, the water quality parameters may not have caused the observed changes in the electrolytes $\left(\mathrm{Na}^{+}, \mathrm{K}^{+}\right.$and $\left.\mathrm{Ca}^{2+}\right)$ of Clarias gariepinus in this study. The ionic changes observed are presumably the result of temporary ionic imbalances associated with increased muscular activities of the fish and subsequent alterations in ionic fluxes across the muscle membrane due to exposure to Kartodim 315EC. Changes in osmoregulation due to ionic imbalance in fish exposed to stressors such as Kartodim 315EC (dimethoate and lambdacyhalothrin) in this study are generally elucidated by measuring the 
blood plasma sodium, potassium, calcium, chloride and or total osmolarity (Burton, 1986). A disturbed osmotic and ionic regulation may affect the ability of the fish to function normally (Kori-Siakpere, 2009). Regulation of plasma ions is accomplished by the kidney, liver, some special organs and the integument, to some extent; in its role as barrier (Bond, 1979). Critical loss of body electrolytes reduces the osmotic concentration and leads to loss of water, which in turn leads to haemo-concentration and circulatory collapse. Surviving through acute challenges therefore relies upon the fish's ability to reduce ion efflux while restoring sufficient uptake to maintain body ion levels.

Other effects observed in the experimental fish include abnormal behaviours such as restlessness, rolling movements, and swimming on the back at higher doses. Loss of movement co-ordination and orientation in water and death occurred in some of the test fish species at the highest concentration of toxicant $(0.02 \mathrm{ml}$ of Kartodim 315EC). Body surface darkening was noticeable in this phase of poisoning, mainly on the dorsal part. Adedeji et al; (2009) reported similar neutral paralytic syndrome in fish poisoned with diazinon.

In conclusion, the changes in the levels of Liver and kidney electrolytes in this study could be an indicator to organ damage and inhibition of enzyme activity. This could be a good bio-maker of the effects of Kartodim 315EC (Dimethoate and Lambda-Cyhalothrin) and similar stressors in the aquatic environment.

\section{Acknowledgement}

We are grateful to the staff of Federal Medical Centre Laboratories Yenagoa and Niger Delta University Post graduate Laboratories for assisting with sample analyses.

\section{References}

[1]. Adedeji, O. B., O. O. Adedeji, O. K. Adeyemo \& S. A. Agbede (2009). Effects of Diazinon on Blood Paramaters in the African Catfish (Clarias garcepinus). The Internet Journal of Hematology, Vol. 5, Number 2.

[2]. Adeyemo, O. K., Agbede, S. A. Olaniyan, A. O., Shoaga, O. A. (2003). The hematological response of Clarias geriepinus to changes in acclimation temperature. African Journal of Biomedical Research, Vol. 6, 105-108.

[3]. Anees, M. A. (1987). Haematological abnormalities in a fresh water Teleost, Channa punctatus (Bloch), exposed to sublethal and chronic levels of three organophosphorus insecticides. Int. J. Ecol. Environ. Sci. 4:53-356

[4]. APHA (American Public Health Association) 1998. Standard methods for examination of water and waste water APHA, Washington DC.

[5]. Beat, G., W. Anres, S. Gunter and S. Mairc. (1997). The Pyrethroids permethrin and Cyhalothrin are potent inhibitors of the mitochondrial complex. J. Pharm. Exp. Therapeutic, pp: 281-860.

[6]. Benarji and Rajendranth (1990). Haematological changes induced by an organophosphorus insecticide in a freshwater fish, Clarias batrachus (Linnacus). Trop. Fresh water. Biol. 2:197-202

[7]. Bond, C. E. (1979). Biology of Fish. Saunders college publishing Philadelphia, U.S.A. 514P.

[8]. Burton, R. F. (1986). Ionic regulation in fish. The influence of acclimation Temperature on plasma composition and apparent set points. Comparative biochemistry and physiology 85A:23-28.

[9]. De Moor I. J. and Bruton M. N. (1988). Atlas of Alien and translocated Indigenous aquatic animals in southern Africa. South African National Scientific programmes Report 114, South Africa.

[10]. Grinshaw, G. (1978). Chemistry Ibadan Evans Brothers Ltd., pp. 32

[11]. Harper, H. A. (1977). Prehled Fysiologicke Chemie. Avicenum, Praha, 1977. pp. 639

[12]. Joshi, P. K. and Manjushree, B. (2000) Toxicity of Cadmium: a comparative study in the air breathing fish Clarias batrachus and in non air one, Ctenopharyngodon idellus J. Fish. Bio. 35:145-149).

[13]. Kori-Siakpere Ovie, (2000). Electrolytes response to sub lethal Concentrations of potassium permanganate in African Catfish: Clarias gariepinus (Burchell, 1822). International Journal of Integrative Biology, 2009, Vol. 5, No. 1, 67.

[14]. Kumar, M., S. P. Trivedi, A. Misra and S. Sharmad (2007). Histopatho logical changes in testis of the freshwater fish, Heteropneustes tossilis (Bloch) exposed to linear alkyl benzene sulphonate (LAS) J. Environ. Biol. 28: 679-684.

[15]. Mohanty, B. K. and Mishra, B. N. (1983). Effects of Mercurial drug (Kajyoli) on Albino rat blood. Journal of Environmental Biology. 4(4) 201-206.

[16]. Mondal, D.S. Barat and M. K. Mukho-Padhgay. (2007). Toxicity of neem pesticides on a fresh water loach, Lepidocephalichthys guntea (Hamilton Buchanan) of Darjeehing District in West Bengal. J. Environ. Biol; 28:119-122.

[17]. Ogamba, E. N., I. R. Inyang and I. K. Azuma (2011). Effect of paraquat Dichloride on some metabolic and Enzyme Parameters of Clarias gariepinus. Current Research Journal of Biological Sciences 3(3): 186-190.

[18]. Oyewo, E. O.; and K. N. Don-Pedro (2006). Acute Toxicity and induced weight changes in laboratory tests with Mn and Cu against Tilapia guineensis (Dumeril) and Tympanotonus Fuscatus (Linne). J Environ. Biology, 27, 327-334.

[19]. Patil, M. and R. S. Kulkarni, (1993). Ovarian and hepatic biochemical response to simaach (a crude form of HCG) in fish, Notopterus notopterus Pallas, under Pesticide Treatment. Geobios, 20:255-259.

[20]. Parveen, M., S. Kumar and P. Singh (2004) Kinetic Analysis of the in Vivo inhibition of Liver Ache in Air breathing fish Clarias batrachus (Linnaeus, 1758). Eu J. Fish Aqua. Sci., 21, 143-144

[21]. Soni, P., S. Sharma, S. Sharma, S. Kumar and K. P. Sharma (2006. A Comparative Study on the toxic effects of textile dye Wastewaters Untreated and treated) on mortality and RBC of freshwater fish Gambusia affinis (Baird and Gerard). J. Environ. Biol., 27, 623-628.

[22]. Svoboda M; V. Luskova, J. Drastihova, V. Zlabek (2001). The effect of Diazinon on haematological indices of common carp (Cyprinus carpio) Acta Vet. Brno, 70:457-465

[23]. Tham L. G; N. Perumal, M. A. Syed, N. A. Shamaan and M. Y. Shukor (2009). Assessment of Clarias batrachus as a source of acetylcholinesterase (ACHE) for the detection of insecticides. J. Environ. Biol. 30 (1), 135-138. 